\title{
Pesantren Modern Al-Junaidiyah Biru di Kabupaten Bone, 1970-2018
}

\author{
Nirwana, Amirullah, Bahri \\ Prodi Pendidikan Sejarah Fakultas Ilmu Sosial Universitas Negeri Makassar \\ nirwanabasri96@gmail.com
}

\begin{abstract}
Abstrak
Penelitian ini bertujuan untuk mengemukakan latar belakang berdirinya Pesantren Modern AlJunaidiyah Biru, perkembangan Pesantren Modern Al-Junaidiyah Biru, dan dampak keberadaan Pesantren Modern Al-Junaidiyah Biru bagi Alumni dan masyarakat dalam bidang agama, pendidikan, dan sosial budaya. Penelitian ini bersifat deskriptif analisis dengan menggunakan metode historis. Melalui tahapan-tahapan, Heuristik (pengumpulan data), kritik (verifikasi), interpretasi (penafsiran) dan historiografi (tulisan sejarah). Hasil penelitian menunjukkan bahwa latar belakang berdirinya Pesantren Modern Al-Junaidiyah Biru dilatarbelakangi oleh KH. Junaid Sulaiman sebagai pendiri pesantren awalnya membuka pengajian kitab kuning yang berlokasi di masjid raya Watampone. Daya tampung masjid raya yang kecil dan minat masyarakat untuk belajar semakin meningkat kemudian menjadi alasan bagi KH. Junaid Sulaiman untuk membangun pusat pendidikan Islam yang lebih besar dan bisa lebih fokus membina generasi muda. Berkat komunikasi yang baik dengan bapak Bupati Kabupaten Bone Andi Muhammad Amir dan Dewan Perwakilan Rakyat maka diperolehlah lokasi yang strategis di JL. Biru dan dengan bantuan berbagai pihak, berdirilah pesantren tersebut yang awalnya diramaikan oleh santri pindahan dari masjid raya mereka kurang lebih 20 orang. Pesantren modern Al-Junaidiyah Biru mengalami perkembangan yang dapat terlihat dengan jelas seperti perkembangan sarana dan prasarana, tenaga pengajar, dan para santrinya yang setiap tahun jumlahnya terus bertambah. Keberadaan Pesantren Modern Al-Junaidiyah Biru ditengah-tengah masyarakat Kabupaten Bone membawa dampak positif baik dalam bidang agama, pendidikan, dan sosial budaya. Dampak yang dirasakan secara langsung bagi masyarakat tentunya menambah pengetahuan baru tentang agama Islam dan mengetahui lebih dalam lagi tentang agama Islam. Keberadaan Pesantren Modern Al-Junaidiyah Biru juga dimanfaatkan oleh masyarakat sekitar sebagai sarana pendidikan bagi anak-anak mereka yang menginginkan anaknya mendalami ilmu keagamaan, dimana Pesantren Modern Al-Junaidiyah Biru sebagai salah satu sarana pendidikan yang menjadi pusat pengembangan ilmu keagamaan dan pendidikan keagamaan melalui sekolah berbasis formal dan nonformal.
\end{abstract}

\section{Kata kunci : Pesantren, Modern dan Biru}

\begin{abstract}
This study aims to reveal the background of the establishment of the Modern boarding school Al-Junaidiyah Biru the development of the Modern boarding school Al-Junaidiyah Biru, and the impact of the existence of Modern boarding school Al-Junaidiyah Biru for alumni and the community in the fields of religion, education, and social culture. This research is a descriptive analysis using the historical method. Through the stages of heuristics (data collection), criticism (verification), interpretation (interpretation) and historiography (historical writing).Tempe and several relevant government parties. then (2) criticism, (3) interpretation and (4) historiography. The results showed that the background of the establishment of the Modern Al-Junaidiyah Biru Pesantren was motivated by KH. Junaid Sulaiman as the founder of the pesantren initially opened the study of the yellow book located in the Watampone great mosque. Small mosque
\end{abstract}


capacity and interest the community to learn to improve has become an excuse for KH. Junaid Sulaiman to build a bigger Islamic education center and can be more focused on fostering the younger generation. Thanks to good communication with the Bupati regent Bone Andi Muhammad Amir and the house of representatives, a strategic location was obtained on JL. Biru and with the help of various parties, the pesantren stood which was initially enlivened by the transfer students from their grand mosque of approximately 20 people. Modern boarding school Al-Junaidiyah Biru has experienced developments that can be seen clearly such as the development of facilities and infrastructure, teaching staff, and students, which are increasing every year. The existence of the Modern boarding school Al-Junaidiyah Biru in the middle of the Bone district community has a positive impact both in the fields of religion, education, and social culture. The impact that is felt directly for the community certainly adds new knowledge about the religion of islamic and knows more about the religion of islamic. The existence of the Modern boarding school Al-Junaidiyah Biru is also used by the surrounding community as a means of education for their children who want their children to study religious knowledge, where the Modern boarding school Al-Junaidiyah Biru as one of the educational facilities which is the center of the development of religious knowledge and religious education through schools formal and informal basis.

\section{Keywords: Boarding School, Modern, Biru}

\section{A. Pendahuluan}

Pendidikan merupakan proses tanpa akhir yang diupayakan oleh siapapun terutama Negara. Sebagai sebuah upaya untuk meningkatkan kesadaran dan ilmu pengetahuan, pendidikan telah ada seiring dengan lahirnya peradaban manusia. Dalam hal inilah, letak pendidikan dalam masyarakat sebenarnya mengikuti perkembangan corak sejarah manusia. (Soyomukti, 2017)

Pendidikan Islam merupakan pendidikan yang secara khas memiliki ciri islami, berbeda dengan konsep pendidikan lain yang kajiannya lebih memfokuskan pada pemberdayaan umat berdasarkan Alqur'an dan Hadist. (Minarti, 2013)Pada awal perkembangan agama Islam di Indonesia, pendidikan Islam dilaksanakan secara informal.

Sistem pendidikan Islam informal ini berlangsung di lingkungan masyarakat. Pelaksanaan sistem pendidikan Islam secara informal berhubungan langsung dengan pola penyebaran Islam di Nusantara, terutama proses pendidikan Islam yang dilakukan di lembaga seperti surau, langgar, atau masjid-masjid. Selanjutnya sistem pendidikan Islam berkembang menjadi sistem pendidikan formal melalui institusi pondok pesantren dan madrasah atau sekolah yang berdasar keagamaan. (Umar, 2016)

Asal etimologi dari Pesantren adalah Pesantrian berarti "tempat santri". Santri atau murid umumnya sangat berbeda-beda mendapat pelajaran dari pemimpin pesantren (kiai) dan oleh para guru (ulama atau ustadz). Pelajaran mencakup berbagai bidang tentang pengetahuan Islam. Di tinjau dari segi sejarah, belum ditemukan data sejarah kapan pertama kali berdirinya pesantren. Ada pendapat mengatakan bahwa pesantren telah tumbuh sejak awal masuknya Islam ke Indonesia, sementara yang lain berpendapat bahwa pesantren baru muncul pada masa Walisongo, dan Maulana Malik Ibrahim dipandang sebagai orang yang pertama mendirikan pesantren. (Daulay, 2007)

Tujuan utama didirikannya suatu pesantren adalah untuk mendalami ilmuilmu agama (tauhid, fiqih, ushul fiqih, tafsir, hadits, akhlak, tasawuf, bahasa arab). Memahami beraneka ragam mata pelajaran agama dengan kemampuan kitab-kitab klasik (Ismail B. , 2014)

Pondok Pesantren merupakan dua istilah yang menunjukkan satu pengertian. Pesantren menurut pengertian dasarnya 
adalah tempat belajar para santri, sedangkan pondok berarti rumah atau tempat tinggal sederhana terbuat dari bambu. Disamping itu, kata pondok berasal dari Bahasa Arab Funduq yang berarti asrama atau hotel. Di Jawa termasuk Sunda dan Madura umumnya digunakan istilah pondok dan pesantren, sedang di Aceh dikenal dengan istilah dayah atau rangkang atau menuasa, sedangkan di Minangkabau disebut surau. Pesantren juga dapat dipahami sebagai lembaga pendidikan dan pengajaran agama, umumnya dengan cara nonklasikal, dimana seorang kiai mengajarkan ilmu agama Islam kepada santri-santri berdasarkan kitab-kitab yang ditulis dalam bahasa Arab oleh Ulama abad pertengahan, dan para santrinya biasanya tinggal di pondok (asrama) dalam pesantren tersebut.

Di Kelurahan Biru Kecamatan Tanete Riattang terdapat sebuah pesantren yang bernama Pesantren Modern Al-Junaidiyah Biru yang dulu dikenal dengan nama Pesantren Ma'had hadits Biru, pesantren ini adalah pertama yang berdiri di Kabupaten Bone. Berdirinya Pesantren Modern Al-Junaidiyah Biru berawal dari gagasan Anre Gurutta KH. Junaid Sulaiman yang digulirkan pada tahun 1969. Peletakan batu pertama dimulai pada tanggal 14 Februari 1970. Hingga pada perkembangannya pada tahun 1973 diresmikan sebagai Pesantren Modern, hingga kemudian berlanjut pada pendirian sekolah formal tingkat Tsanawiyah dan Aliyah. Kompleks pesantren yang dibangun di atas tanah berukuran kurang lebih $1775 \mathrm{~m} 2$, terlihat gedung berlantai dua, kesan pendidikan modern begitu kental, dengan gedung sekolah, asrama dan perkantoran yang berdiri dengan arsitektur modern layaknya gedung dan sekolah yang umumnya ada di Kota Watampone, cukup menggambarkan pesantren ini fokus pada dunia pendidikan dan keilmuan. Namun yang mencolok dari pesantren ini adalah selain tumbuh suburnya khazanah keilmuan, bukan hanya sekolah-sekolah yang penuh dengan corak ke-Islamannya tapi juga mereka masih mempertahankan gaya lama dengan sistem pondoknya, khususnya mempertahankan pembinaan Qismul Huffadz atau penghapal Al'Quran.

Pesantren Modern Al-Junaidiyah Biru merupakan pesantren di Kabupaten Bone yang pertama mendapatkan kepercayaan dari Kemenang untuk mengelola kurikulum PDF tingkat Ulya, dengan mendapat keputusan Dirjen Pendidikan Islam Nomor 1874 tahun 2018 tentang izin penerimaan Pendidikan Diniyah Formal tingkat Ulya atau sederajat Madrasah Aliyah, dan memulai tahun ajaran baru dengan membuka satu kelas.Pendidikan Diniyah Formal (PDF) di Pesantren Modern Al-Junaidiyah Biru merupakan salah satu entitas kelembagaan pendidikan keagamaan Islam yang bersifat formal guna menghasilkan alumni Mutafaqqih fiddin ( ahli ilmu agama islam) yang mampu mendalami kitab-kitab dari aslinya. Kurikulum yang diterapkan di Pendidikan Diniyah Formal (PDF) terdiri atas pendidikan umum dan lebih menonjolkan pendidikan Agama Islam yang berbasis kitab kuning.

Penelitian tentang Pesantren yang dilakukan di Kelurahan Biru Kecamatan Tanete Riattang Kabupaten Bone merupakan suatu kajian sejarah pendidikan Islam dengan menggunakan pendekatan Ilmu Sejarah secara khusus. Meskipun telah banyak lahir penelitian-penelitian maupun tulisan-tulisan yang menyangkut atau terkait dengan pesantren. Misalnya skripsi yang berjudul "Pesantren Yasrib Lapajung di Kabupaten Soppeng" yang ditulis oleh Melia Ratnasari yang memberikan gambaran tentang pondok pesantren Yasrib yang merupakan salah satu unit dari Yayasan Perguruan Islam Beowe (Yasrib) sebagai manifestasi dari rasa tanggung jawab akan kewajiban untuk mencerdasarkan kehidupan bangsa pada umumnya dan pembangunan umat Islam di Kabupaten Soppeng. Terdapat perbedaan temporal terhadap penelitian sebelumya dengan penelitian yang dilakukan oleh Melia Ratnasari yakni fokus pada penelitian 
ini terletak di Kabupaten Bone. Penelitian lain yang terkait dengan pondok pesantren ditulis oleh Satriani dalam Skripsinya yang berjudul " Pondok Pesantren Puteri Ummul Mukminin Aisyiyah Wilayah Sulawesi Selatan" yang ditulis oleh Satriani, yang memberikan gambaran tentang Pondok Pesantren Puteri Ummul Aisyiyah dibangun sejak tahun 1984.Tahun 1987, pondok ini mulai menerima santri baru yang pada saat itu masih berjumlah 17 orang. Dan pesantren ini telah banyak mengalami perkembangan sejak awal berdirinya sampai saat ini. Mulai dari bangunan pondok pesantren sampai jumlah santrinya yang awalnya hanya 17 orang dan sampai saat ini lebih dari 1112 orang. Terdapat perbedaan temporal terhadap penelitian sebelumnya dengan penelitian yang dilakukan oleh Satriani yakni fokus pada penelitian ini terletak di Kabupaten Bone.

\section{B. Metode Penelitian}

Penulisan karya ilmiah terdapat cara yang digunakan untuk menyusun karya ilmiah tersebut. Hal ini disebut dengan metode, metode berasal dari bahasa Yunani yaitu methodos yang artinya cara atau jalan. Menurut Kennet D. Bailey, metode adalah teknik penelitian atau alat yang dipergunakan untuk mengumpulkan data.

\section{Heuristik}

Heuristik merupakan tahap pengumpulan sumber- sumber sejarah yang terkait dengan topik penelitian. Peneliti mengumpulkan informasi mengenai Pesantren Modern Al-Junaidiyah Biru di Kabupaten Bone dengan menempuh dua cara yaitu penelitian lapangan yang terdiri dari observasi dan wawancara langsung serta penelitian pustaka.

Metode observasi menggunakan pengamatan dan penginderaan langsung terhadap kondisi objek dimana penulis melakukan penelitian secara langsung terhadap kegiatan proses belajar mengajar yang berlangsung di Pesantren Modern AlJunaidiyah Biru, kegiatan ekstrakurikuler yang ada di Pesantren Modern AlJunaidiyah Biru, serta pengajian dan pengajaran kitab kuning klasik yang dibawakan oleh ustadz dan ustadzah di Pesantren Modern Al-Junaidiyah Biru.

Wawancara merupakan metode pengumpulan data yang dilakukan secara langsung oleh peneliti dengan mempertanyakan berbagai hal yang terkait dengan Pesantren Modern Al-Junaidiyah Biru. Wawancara tersebut dilakukan bersama Dliyauddin Huzaifah S.HI yang merupakan sekertaris Pondok Pesantren Modern Al-Junaidiyah Biru, Drs. H. Maharajuddin yang merupakan sekertaris yayasan, Drs. H. M. Ishak Ahmad yang merupakan kepala bagian logistik di Pesantren Modern Al-Junaidiyah Biru, Drs. Ansari, S.Pd.I, M,Pd.I sebagai Kepala Madrasah Tsanawiyah, Murniati, S.Ag. M.Pd, sebagai Kepala Madrasah Aliyah, Imas Aas Asroriyah, S.Pd.I sebagai Kepala Madrasah Tahfidz Qur'an serta para staf pengajar, staf tata usaha, alumni dan dari kalangan masyarakat.

Penelitian pustaka merupakan langkah pengumpulan data dengan mencari bukubuku yang ada hubungannya dengan masalah yang akan diteliti. Peneliti mencari buku tentang pondok pesantren, buku pendidikan agama Islam di perpustakaan umum UNM, perpustakaan wilayah Makassar, perpustakaan daerah Kabupaten Bone, serta mencari skripsi yang tersedia di Perpustakaan Jurusan Pendidikan Sejarah FIS UNM.

\section{Kritik}

Hasil pengerjaan studi sejarah yang akademis atau kritis memerlukan faktafakta yang telah teruji. Oleh Karena itu, data- data yang diperoleh melalui tahapan heuristik terlebih dahulu harus dikritik atau disaring sehingga diperoleh fakta- fakta yang seobjektif mungkin. Kritik tersebut berupa kritik tentang otentitasnya (kritik eksteren) maupun kredibilitas isinya (kritik intern), dilakukan ketika dan sesudah pengumpulan data berlangsung. Sumber sejarah yang telah dikritik menjadi data sejarah. 


\section{Interpretasi}

Proses perjalanan penelitian sejarah yang bermuara pada metode sejarah dengan empat tahap, heuristik, kritik, interpretasi, dan historiografi, pada hakikatnya berpuncak pada tahap interpretasi. Heuristik dan kritik berfungsi untuk menyeleksi sumber-sumber atau data-data sejarah, sehingga didapatkan fakta-fakta atau bukti-bukti sejarah yang valid dan reliabel.Sedang dalam tahap interpretasi dan historiografi fungsi utamanya terletak pada interpretasi. Interpretasi berarti menafsirkan atau memberi makna kepada fakta-fakta (facts) atau bukti-bukti sejarah (evidences). Interpretasi diperlukan karena pada dasarnya bukti-bukti sejarah sebagai saksi (witness) realitas di masa lampau adalah hanya saksi-saksi bisu belaka. Fakta-fakta atau bukti-bukti dan saksi-saksi sejarah itu tidak bisa berbicara sendiri mengenai apa yang disaksikannya dari realitas masa lampau. Untuk mengungkapkan makna dan signifikansi dirinya fakta-fakta dan bukti-bukti sejarah masih harus menyandarkan dirinya pada kekuatan informasi dari luar (extrinsic informatife). (A, 2015)

\section{Historiografi}

Dalam kaitannya dengan historiografi, yaitu proses penulisan sejarah banyak aspek yang terkait didalamnya. Menurut Hexter, proses pengumpulan bukti-bukti sejarah, pengeditan sumber sejarah, penggunaan pemikiran dan imajinasi sejarah, dan sebagainya merupakan Suatu proses yang tidak dapat dipisahkan dari historiografi. (Haryono, 1995)

\section{Tinjauan Umum Penelitian}

Di Kabupaten Bone Kecamatan Tanete Riattang Kelurahan Biru terdapat sebuah pesantren modern yang bernama Pesantren Modern Al-Junaidiyah Biru. Letaknya $2 \mathrm{~km}$ dari pusat kota Watampone, bagian sebelah selatan kurang lebih $180 \mathrm{~km}$ dari kota Makassar, ibu kota provinsi Sulawesi Selatan. Pesantren Modern Al-Junaidiyah Biru merupakan pesantren modern pertama yang berdiri di Kabupaten Bone pada tahun 1970. Santri yang mendaftarkan diri di Pesantren Modern AlJunaidiyah Biru terlebih dahulu harus membayar uang pangkal atau uang masuk senilai Rp. 6.000.000 dan infaq bulanan senilai Rp. 700.000 termasuk perlengkapan yang ditanggung oleh pihak pesantren seperti : lemari pakaian, perlengkapan tidur, perlengkapan makan, pakaian batik, kitab kuning klasik, dan Al-Qur'an khusus hafalan santri selama berada di Pesantren. Santri yang belajar di pesantren tersebut tidak hanya dari daerah lokal saja tetapi banyak juga santri yang berasal dari luar daerah seperti dari Palopo, Kalimantan, Jakarta, Sorong, dan Kendari. Hal ini membuktikan bahwa Pesantren Modern Al-Junaidiyah Biru tetap menjaga eksistensinya baik dalam daerah maupun keluar daerah

\section{Pembahasan}

\section{Perkembangan Pesantren Modern Al- Junaidiyah Biru}

\section{a. Sarana dan Prasarana}

Pengertian sarana dan prasarana secara etimologi memiliki perbedaan, namun keduanya memiliki keterkaitan yang sangat penting sebagai alat penunjang keberhasilan suatu proses yang dilakukan dengan kata lain, suatu proses dengan kegiatan yang akan dilakukan tidak akan mencapai hasil yang diharapkan sesuai dengan rencana jika sarana dan prasarana tidak tersedia. Sarana adalah segala sesuatu yang dipakai sebagai alat untuk mencapai makna dan tujuan, sebagai contoh; sarana pendidikan diartikan sebagai alat untuk mencapai tujuan pendidikan, misalkan buku, tas, pulpen, komputer. (M, 2008)

Sarana berarti segala sesuatu yang dipakai untuk mengerjakan sesuatu dalam mencapai tujuan. Sedangkan kaitannya dengan pendidikan, sarana adalah peralatan, bahan dan perlengkapan yang secara langsung dipergunakan dan menunjang proses pembelajaran. Dalam konteks proses belajar mengajar, sarana dapat berupa gedung, ruang kelas, meja, 
PATTINGALLOANG

(C) Jurnal Pemikiran Pendidikan dan Penelitian Kesejarahan

kursi, serta alat-alat dan media pengajaran. Sedangkan prasarana adalah segala sesuatu yang merupakan penunjang utama terselenggarakannya suatu proses, sebagai contoh; prasarana pendidikan berarti alat tidak langsung untuk mencapai tujuan pendidikan misalnya lokasi, bangunan sekolah, lapangan olahraga, dan lain-lain. Penggunaan sarana dan prasarana adalah pemanfaatan segala jenis barang yang sesuai dengan kebutuhan secara efektif dan efesien. Dalam hal pemanfaatan sarana dan prasarana, harus mempertimbangkan halhal yakni tujuan yang akan dicapai, kesesuaian antar media yang akan digunakan dengan materi yang akan dibahas, tersedianya sarana dan prasarana penunjang, dan karakteristik siswa. (Reza, 2016)

Manajemen sarana dan prasarana pendidikan dapat diartikan sebagai proses pengadaan dan pendayagunaan komponenkomponen yang secara langsung maupun tidak langsung jalannya proses pendidikan untuk mencapai tujuan pendidikan secara efektif dan efesien. Dari defenisi tersebut menunjukkan bahwa sarana dan prasarana yang ada harus didayagunakan dan dikelola untuk kepentingan proses pembelajaran. Pengelolaan sarana dan prasarana tersebut dimaksudkan agar penggunaannya dapat berjalan dengan efektif dan efesien. Kegiatan pengelolaan ini meliputi kegiatan perencanaan, pengadaan, pengawasan, penghapusan, penggunaan/pemanfaatan dan tanggung jawab. (Indrawan, 2015)

\section{Jumlah Sarana dan Fasilitas di Pesantren Modern Al-Junaidiyah Biru}

\begin{tabular}{|l|l|l|}
\hline No & Jenis Sarana dan Fasilitas & Jumlah \\
\hline 1. & Ruangan & \\
\hline & $\begin{array}{l}\text { a. Ruangan Kepala } \\
\text { Sekolah }\end{array}$ & 5 \\
\hline & b. Kantor & 5 \\
\hline & c. Guru & 6 \\
\hline & d. Kelas & 27 \\
\hline & e. Lab Bahasa & 1 \\
\hline
\end{tabular}

\begin{tabular}{|c|c|c|}
\hline & f. Lab. Komputer & 2 \\
\hline & g. $\quad$ Lab. IPA & 1 \\
\hline & h. Ruangan Tata Usaha & 4 \\
\hline & i. $\quad$ Masjid & 1 \\
\hline & j. Aula Serbaguna & 1 \\
\hline & k. Ruangan Osis & 1 \\
\hline & 1. Rusunawa & 12 \\
\hline & m. Ruang Makan & 1 \\
\hline & $\begin{array}{lll}\text { n. } & \text { Sanggar } & \text { Bakti } \\
\text { Pramuka } & \\
\end{array}$ & 1 \\
\hline & o. Ruangan UKS & 1 \\
\hline & p. Perpustakaan & 1 \\
\hline & q. Koperasi & 1 \\
\hline 2. & $\begin{array}{l}\text { Meubelair/Perabot } \\
\text { Madrasah }\end{array}$ & \\
\hline & a. Meja Guru & 42 \\
\hline & b. Kursi Guru & 42 \\
\hline & c. Meja Siswa & 780 \\
\hline & d. Kursi Siswa & 780 \\
\hline & e. Meja Kantor & 7 \\
\hline & f. Kursi Kantor & 7 \\
\hline & g. Kursi Tamu & 6 \\
\hline & h. Lemari & 8 \\
\hline & i. Filling Cabinet & 5 \\
\hline 3. & Sanitasi Air Bersih & \\
\hline & a. Kamar/WC & 40 \\
\hline & b. MCK & 16 \\
\hline & c. Sumur Biasa & 7 \\
\hline & d. PDAM & 1 \\
\hline 4. & Sumber listrik & \\
\hline & a. PLN & 1 \\
\hline & b. Gen Set & 1 \\
\hline 5. & Alat Mesin Kantor & \\
\hline & a. Komputer & 15 \\
\hline & b. Over Head Proyektor & 7 \\
\hline & c. Laptop & 3 \\
\hline
\end{tabular}

Sumber: Arsip Sekertaris Pondok Pesantren Modern Al-Junaidiyah Biru.

\section{b. Tenaga Pengajar dan Santri \\ 1) Tenaga Pengajar}

Guru sering diartikan sebagai orang yang bertanggung jawab terhadap perkembangan siswa dengan mengupayakan perkembangan seluruh potensi fitrah siswa, baik potensi kognitif, 
potensi afektif, maupun potensi psikomotorik. Dalam sebuah lembaga pendidikan, baik formal ataupun nonformal tentunya memiliki beberapa komponen penting salah satunya adalah guru atau tenaga pendidik. Guru memiliki tugas sebagai pengajar sekaligus pendidik dalam mengembangkan suatu ilmu pengetahuan yang diberikan kepada peserta didiknya. Guru sebagai salah satu unsur dibidang kependidikan harus berperan serta secara aktif dan menempatkan kedudukannya sebagai tenaga professional, sesuai dengan tuntutan masyarakat yang semakin berkembang. (Sardiman, 2005)

Sejak dibukanya Madrasah Tsanawiyah di Pesantren Modern Al-Junaidiyah Biru tahun 1986, maka proses belajar mengajar langsung diterapkan. Tenaga pengajar dalam hal ini ustadz/ustadzah yang dipekerjakan belum seberapa. Salah satunya tenaga pengajar yang bernama Ishak Ahmad yang mulai mengajar di MTs tahun 1986. Beliau mengajar santri mata pelajaran bahasa arab dan mata pelajaran lainnya. Meskipun awal dibukanya MTs santrinya relatif sedikit, tetapi tidak menurunkan semangat beliau untuk tetap mengabdi di pesantren tersebut. Gaji yang diperoleh pak Ishak Ahmad tidak seberapa dan berasal dari potongan gaji PNS yang bekerja di Kementerian Agama di Kabupaten Bone. (Ahmad, 2019)

\section{2) Santri}

Santri merupakan unsur terpenting yang akan menentukan keberhasilan pondok pesantren. Sebab tanpa adanya santri, maka proses pewarisan nilai dan ajaran-ajaran dalam pondok pesantren tidak akan berhasil. Santri adalah komponen yang tidak dapat dilepaskan dari kehidupan ulama, karena berbicara mengenai kehidupan ulama pasti juga akan menyangkut kehidupan santri yang merupakan murid sekaligus pengikut dan pelanjut ulama yang bersangkutan.

Jika dirunut dengan tradisi pesantren, terdapat dua kelompok santri, yakni: santri mukim yakni murid-murid yang berasal dari daerah jauh dan menetap di pesantren. Santri yang sudah lama mukim di pesantren biasanya menjadi kelompok tersendiri dan sudah memikul tanggung jawab mengurusi kepentingan pesantren sehari-hari, seperti halnya mengajar santri-santri muda tentang kitabkitab tingkatan rendah dan menengah. Sedangkan santri kalong adalah muridmurid yang berasal dari desa sekelilingnya, yang biasanya mereka tidak tinggal di pesantren kecuali kalau waktu-waktu belajar saja, mereka bolak-balik dari rumah. (Hidayat, 2016)

\section{Keadaan Santri MTs di Pesantren Modern Al-Junaidiyah Biru 2010-2018}

\begin{tabular}{|c|c|c|c|c|}
\hline No & $\begin{array}{l}\text { Tahun } \\
\text { Ajaran }\end{array}$ & $\begin{array}{l}\text { Laki- } \\
\text { Laki }\end{array}$ & $\begin{array}{l}\text { Pere } \\
\text { mpua } \\
n\end{array}$ & $\begin{array}{l}\text { Jumla } \\
\text { h }\end{array}$ \\
\hline 1. & $2009 / 2010$ & 93 & 63 & 156 \\
\hline 2. & $2010 / 2011$ & 96 & 58 & 154 \\
\hline 3. & $2011 / 2012$ & 117 & 67 & 184 \\
\hline 4. & $2012 / 2013$ & 151 & 75 & 226 \\
\hline 5. & $2013 / 2014$ & 183 & 90 & 273 \\
\hline 6. & $2014 / 2015$ & 186 & 107 & 293 \\
\hline 7. & $2015 / 2016$ & 199 & 104 & 303 \\
\hline 8. & $2016 / 2017$ & 198 & 103 & 301 \\
\hline 9. & $2017 / 2018$ & 192 & 122 & 314 \\
\hline 10. & $2018 / 2019$ & 224 & 154 & 378 \\
\hline \multicolumn{2}{|c|}{ Jumlah } & 1639 & 943 & 2582 \\
\hline
\end{tabular}

Sumber: Buku Laporan Pendidikan PM. Al-Junaidiyah Biru 2018.

\section{c. Kurikulum dan Strategi Pembelajaran \\ 1) Kurikulum}

Kata kurikulum berasal dari bahasa Yunani yang semula digunakan dalam bidang olahraga, yaitu currere yang berarti jarak tempuh lari, yakni jarak yang harus ditempuh dalam kegiatan berlari mulai dari start hingga finish. Pengertian ini kemudian diterapkan dalam bidang pendidikan. Dalam bahasa Arab, istilah kurikulum diartikan dengan manhaj, yakni jalan yang terang, atau jalan terang yang dilalui oleh manusia pada bidang kehidupannya. Dalam konteks pendidikan, kurikulum berarti jalan terang yang dilalui oleh pendidik/guru 
dengan peserta didik untuk mengembangkan pengetahuan, keterampilan dan sikap serta nilai-nilai. (Muhaimin, 2014)

Kurikulum yang diterapkan di Pesantren Modern Al-Junaidiyah Biru terdiri atas tiga yaitu; kurikulum pesantren, kurikulum Kementerian Agama, dan kurikulum umum. Kurikulum pesantren terdiri dari nahusharaf, mahfudzat, ushul fiqhi, ulumul hadits, ulumul Qur'an, kaligrafi, dan Qur'an hifdan. Kurikulum Kementerian Agama terdiri dari al-Qur'an hadits, akidah akhlak, fiqhi, bahasa Arab, dan sejarah kebudayaan Islam. Sedangkan kurikulum umum terdiri dari bahasa Indonesia, bahasa inggris, biologi, sejarah, pkn, sosiologi, matematika dan lain sebagainya. Semua kurikulum yang ada di pesantren di terapkan dan diajarkan didalam kelas sebagaimana proses belajar mengajar berlangsung. Adapun aktivitas santri mulai jam 07.10- 01.30 adalah belajar mengajar yang dilakukan secara formal didalam kelas, dan isoma. Kemudian setelah shalat dzuhur dilanjutkan dengan kegiatan ekstrakurikuler.

\section{d. Strategi Pembelajaran}

\section{1) Model Pembelajaran santri Al- Junaidiyah Biru}

Model pembelajaran santri di Pesantren Modern Al-Junaidiyah Biru terdiri dari dua bentuk, yaitu; model full day, dan boarding school. Model full day diorientasikan pembelajaran pada santri yang tinggal atau mondok di pesantren. Maksudanya, santri lokal yang tidak tinggal di asrama aktivitas pembelajaran dimulai pada pagi hari sampai menjelang siang hari yang diperuntukkan untuk santri Raudhatul Athfal. sedangkan untuk santri TPA/TPQ jam belajar dimulai setelah dzuhur sampai sore hari. Selanjutnya untuk model pembelajaran boarding school santri harus mondok atau diasramakan dan wajib mengikuti regulasi, kode etik, dan proses pembelajaran yang ditetapkan oleh pondok pesantren. Aktivitas pembelajaran model boarding school terbagi menjadi tiga waktu yaitu aktivitas pagi, aktivitas sore, dan aktivitas malam. Hal tersebut dibuat dan dirancang agar keseharian aktivitas belajar para santri terpenuhi. Baik proses pembelajaran yang dilakukan didalam kelas formal maupun diluar kelas formal. Di samping itu, santri juga dibatasi ruang geraknya untuk tidak keluar meninggalkan asrama kecuali jika ada izin dari pihak pesantren atau pembina.

\section{2) Model Pendalaman Bahasa}

Pendalaman dan penguasaan bahasa sangat ditekankan di Pesantren Modern AlJunaidiyah Biru. Bahasa yang digunakan ada empat jenis yaitu bahasa bugis, bahasa inggris, bahasa Indonesia, dan bahasa Arab. Keempatnya dapat direpresentasikan sebagai bahasa lokal, bahasa nasional, dan internasional. Bahasa bugis digunakan dalam dua segmen yaitu, pertama bahasa bugis digunakan pada kurikulum dan pembelajaran muatan lokal tingkat MTs. Kedua, bahasa bugis digunakan dalam latihan dakwah atau ceramah agama. hal tersebut dianggap penting karena bahasa bugis merupakan bahasa lokal dari daerah Bone sendiri jadi tidak heran jika pihak pesantren memasukkan bahasa bugis dalam pembelajaran latihan dakwah atau ceramah agama.

Mayoritas santri yang diajar berasal dari etnis bugis namun tidak sedikit pula dari mereka yang tidak paham dalam berbahasa bugis. Berbeda dengan bahasa bugis, bahasa Indonesia sebagai bahasa nasional dijadikan bahasa sehari-hari para santri di asrama atau bahkan didalam kelas. Bahasa Indonesia merupakan bahasa yang umum digunakan oleh para santri baik sesama santri, pihak pesantren, maupun kepada ustadz atau ustadzah. Meskipun Pesantren Modern Al-Junaidiyah Biru berada di daerah Bone yang mayoritas masyarakatnya berbahasa bugis tetapi bahasa Indonesia tetap yang digunakan dalam percakapan sehari-hari dalam berkomunikasi. 
Model pendalaman bahasa selanjutnya adalah bahasa asing yaitu bahasa Arab dan bahasa inggris.Kedua bahasa ini diajarkan kepada santri didalam bimbingan khusus dua bahasa yaitu bahasa Arab dan Inggris. Masing-masing pembina dari bimbingan tersebut memiliki metode dan cara tersendiri dalam mengajar. Para santri dibagi dan masing-masing memiliki jadwal tersendiri untuk latihan sehingga dapat dipastikan semua santri dibina dan diajar dengan baik.

\section{e. Prestasi}

Sejak didirikannya Pesantren Modern Al-Junaidiyah Biru sebagai lembaga pendidikan Islam pertama di kabupaten Bone tentu sudah banyak menorehkan prestasi dibidang olahraga, seni, dan penghafal Al-Qur'an.Baik pada event lokal daerah, regional, maupun tingkat nasional. Berikut sejumlah prestasi yang diperoleh Pesantren Modern Al-Junaidiyah Biru dari tahun 2014-2019. Tahun 2018 Pesantren Modern Al-Junaidiyah Biru mendapat juara II dalam lomba olympiade matematika UNHAS tingkat Kabupaten, masuk 10 besar dalam pemilihan duta pariwisata Kabupaten Bone, juara II lomba dai muda RRI Bone tingkat Kabupaten, juara I lomba kompetisi sains madrasah fisika tingkat Kabupaten, juara I dalam perkemahan pramuka santri nusantara tingkat Kabupaten, juara II lomba pidato kebangsaan dalam peringatan HUT Kemerdekaan RI di polres Bone, juara III lomba Arabic song dalam pentas budaya Arab 3 di UNHAS tingkat Provinsi, juara II lomba musikalisasi puisi dalam kemah dan lomba kreativitas pramuka tingkat penegak se Sul-Sel dan Sul-Bar tingkat Provinsi, juara III lomba standard camp se Sul-Sel dan Sul-Bar tingkat provinsi, juara I lomba futsal dalam hari amal bakti Kemenag Kabupaten Bone tingkat kabupaten, dan juara III lomba Futsal Athira Olympic tingkat provinsi.
Dalam tahun 2019 Pesantren Modern Al-Junaidiyah Biru mengikuti lomba musabaqah hifdzil Qur'an Hadits di kedubes Arab Saudi tingkat Internasional, juara I cerdas cermat putri di porseni antar pondok pesantren se Sul -Sel Bar di Mangkosso Kabupaten Barru tingkat Provinsi, juara III lomba hafalan 100 hadits di STQ tingkat Kabupaten Sinjai, juara I lomba hafalan 20 juz di STQ tingkat Kabupaten Bone, juara I lomba hafalan 30 juz tingkat Kabupaten, juara I lomba hafalan 30 juz dalam STQ Kabupaten Sinjai, juara II lomba hafalan 20 juz dalam STQ Kabupaten maros, dan juara III hafalan hadits dalam STQ Kabupaten Sinjai.

Prestasi yang telah diraih dan ditorehkan oleh para santri dan alumni yang ada di Pesantren Modern AlJunaidiyah Biru tidak terlepas dari usaha dan kerja keras serta belajar dengan tekun yang dilakukan oleh para santri sebelum mengikuti lomba.Sehingga tidak heran jika prestasi yang diraih rata-rata mendapatkan juara I, II, dan III.Tidak hanya bersaing dalam tingkat daerah, provinsi, nasional, tetapi bisa sampai ke kancah internasional.Berkat keseriusan para santri dan sistem pembelajaran yang mendukung, maka sejumlah prestasi telah ditunjukkan oleh para santri di Pesantren Modern AlJunaidiyah Biru.

\section{Dampak Pesantren Modern Al- Junaidiyah Biru}

Adanya sebuah lembaga pendidikan agama Islam, didalam masyarakat perkotaan seperti Pesantren Modern AlJunaidiyah Biru tentu membawa dampak bagi yang ada disekelilingnya. Masyarakat perkotaan yang jamak atau yang biasanya dikenal sebagai masyarakat heterogen secara kultur dan keberagaman pemahaman agama, tentu menimbulkan dampak yang tidak kecil bagi komunitas masyarakat dan alumni dari pesantren 
tersebut baik secara langsung maupun tidak langsung.

\section{a. Dampak Pesantren Modern Al- Junaidiyah Biru Terhadap Alumni}

Dari sekian banyak alumni yang ditamatkan, kurang lebih $90 \%$ yang melanjutkan studinya ke jenjang perguruan tinggi baik perguruan tinggi dalam negeri maupun keluar negeri. Sedang santri yang tidak lanjut ke perguruan tinggi ditawarkan pekerjaan untuk mengabdi ke pesantren menjadi pembina. Alumni Pesantren yang mendaftar di perguruan tinggi seperti UNM, UNHAS, UIN, IAIN, AL-AZHAR Mesir dan STTP Malang.

Ada

dua sistem yang digunakan pihak pesantren untuk memfasilitasi alumninya untuk lanjut. Pertama, mengikutsertakan alumni yang berprestasi dan memiliki nilai tinggi untuk ikut berkompetisi dalam program mahasiswa jalur khusus yang diselenggarakan oleh perguruan tinggi negeri maupun swasta. Kedua, santri yang berprestasi diupayakan untuk melanjutkan studinya di dalam negeri maupun ke luar negeri dengan memperoleh beasiswa. Kedua sistem yang digunakan pihak pesantren tersebut sebagai wujud kepeduliaan terhadap para alumninya yang tamat. Pesantren Modern Al-Junaidiyah Biru sebagai lembaga pesantren modern tidak hanya memperhatikan santrinya ketika mondok saja tetapi pasca tamatnya juga diperhatikan. Hal ini membuktikan bahwa pihak pesantren tetap peduli terhadap masa depan pendidikan para santrinya. (Makmur, 2019)

Sampai saat ini, Pesantren Modern AlJunaidiyah Biru telah memiliki ratusan alumni yang sudah tersebar di beberapa daerah, ada yang sudah menjadi pejabat atau pengusaha, dan tidak kurang pula yang telah jadi da'I kondang, baik di pelosok desa maupun di perkotaan. Alumni yang telah menjadi pejabat yaitu Dr. Alimin, M.Ag yang menjabat sebagai Kepala P3M UIN Syarif Hidayatullah, Muh. Tonang, S.Ag., M.Ag yang menjabat sebagai Kabag Humas Kanwil Sulawesi Selatan, dan Dr. Muhaimin, M.A., yang menjabat sebagai
Kepala Penjaminan Mutu STAIN Palopo. Sedangkan alumni yang telah menjadi pengusaha yaitu Jusman yang mempunyai PT. Surya Santana. (Hermanto, 2012)

\section{b. Dampak Pesantren Modern Al- Junaidiyah Biru Bagi Masyarakat Sekitar \\ 1) Bidang Agama}

Sejak awal didirikannya, fungsi utama pesantren adalah menyiapkan santri mendalami dan menguasai ilmu agama Islam atau lebih dikenal dengan Tafaqquh fi al-din, yang diharapkan dapat mencetak kader-kader ulama dan turut mencerdaskan masyarakat Indonesia dan melakukan dakwah menyebarkan agama Islam serta benteng pertahanan umat dalam bidang akhlak. Pesantren sebagai lembaga pendidikan memiliki akar kuat (indigenous) pada masyarakat muslim Indonesia, dalam perjalanannya mampu menjaga dan mempertahankan keberlangsungan dirinya serta memiliki model pendidikan multi aspek. Santri tidak hanya dididik menjadi seseorang yang mengerti ilmu agama, tetapi juga mendapat tempaan kepemimpinan yang alami, kemandirian, kesederhanaan, ketekunan, kebersamaan, dan sikap positif lainnya.Modal inilah yang diharapkan melahirkan masyarakat yang berkualitas dan mandiri sebagai bentuk partisipasi pesantren dalam menyukseskan tujuan pembangunan nasional. (Usman, 2013)

Keberadaan Pesantren Modern AlJunaidiyah Biru di tengah-tengah masyarakat Kelurahan Biru tentu membawa dampak tersendiri dalam hal keagamaan bagi masyarakat dan santri. Dampak yang dirasakan secara langsung bagi masyarakat tentunya menambah pengetahuan baru tentang agama Islam dan mengetahui lebih dalam lagi tentang agama Islam. Dulunya masyarakat Kelurahan Biru Kecamatan Tanete Riattang sebelum didirikan pesantren sangat jarang terlihat masyarakat ke masjid untuk melaksanakan shalat berjamaah. Tetapi, setelah Pesantren Modern Al-Junaidiyah Biru berdiri ditengah-tengah masyarakat Kelurahan Biru terlihat sangat jelas perbedaan sebelum dan 
sesudah berdirinya pesantren. Masyarakat Kelurahan Biru memiliki kesadaran dalam hal keagamaan dengan melaksanakan shalat berjamaah di masjid. Dalam hal ini jelas tampak bahwa keberadaan Pesantren Modern Al-junaidiyah Biru membawa dampak positif dalam hal keagamaan bagi masyarakat.

\section{c. Bidang Pendidikan}

Islam memiliki ajaran yang khas dalam bidang pendidikan, Islam memandang bahwa pendidikan adalah hak bagi setiap orang (education for all), laki-laki atau perempuan, dan berlangsung sepanjang hayat. Dalam bidang pendidikan Islam memiliki rumusan yang jelas dalam bidang tujuan, kurikulum, guru, metode, sarana, dan lain sebagainya. (Nata, 2001)

Sebelum berdirinya Pesantren Modern Al-Junaidiyah Biru, masyarakat yang tinggal disekitar pesantren dulunya tidak terlalu memprioritaskan pendidikan keagamaan bagi anaknya. Hal ini disebabkan karena pada saat itu belum ada pesantren yang berdiri di Kabupaten Bone yang mampu melahirkan anak-anak yang memiliki pengetahuan secara Islami. Keberadaan Pesantren Modern Al-Junaidiyah Biru dimanfaatkan oleh masyarakat sekitar sebagai sarana pendidikan bagi anak-anak mereka yang menginginkan anaknya mendalami ilmu keagamaan, dimana Pesantren Modern Al-Junaidiyah Biru sebagai salah satu sarana pendidikan yang menjadi pusat pengembangan ilmu keagamaan dan pendidikan keagamaan melalui sekolah berbasis formal dan nonformal mulai dari RA, MTS, MA, PDF, TPA/TPQ, dan MTQ.

Selain karena sarana dan prasarana yang sudah memadai, pembinaan bakat dan minat pada bidang seni dan olahraga bagi para santri, juga adanya penguasaan bahasa asing seperti bahasa Arab dan bahasa inggris. Keunggulan lainnya ialah jumlah personil guru yang memadai, potensi siswa yang cukup memadai, kerjasama sesama warga pesantren yang baik, keamanan lingkungan sekolah yang mendukung, santri dan pembina berdomisili di dalam pesantren. Dengan adanya pondok pesantren yang berlokasi di Kelurahan Biru tidak ada lagi anak-anak yang putus sekolah.Bahkan, masyarakat yang jauh dari lokasi pesantren juga menyekolahkan anaknya ke Pesantren Modern AlJunaidiyah Biru.Selain karena kualitas pendidikan di pesantren yang dianggap bagus juga karena keinginan orang tua agar anaknya memperoleh pendidikan secara Islami yang bisa diaplikasikan secara langsung dalam kehidupan sehari-hari dan tidak hanya berguna bagi dunia saja tetapi juga diakhirat kelak. (Saigah, 2019)

\section{d. Bidang Sosial Budaya}

Kepercayaan terhadap tradisi leluhur masih banyak ditemukan dan dipraktikkan oleh masyarakat di berbagai wilayah Indonesia. Dalam masyarakat Bugis Sulawesi Selatan, misalnya praktik-praktik seperti ini masih dijumpai. Apresiasi masyarakat terhadap mitologi leluhur dan kepercayaan kepada makhluk gaib yang memiliki kekuatan supranatural masih dipelihara, meskipun dibeberapa tempat terutama pada masyarakat perkotaan kepercayaan seperti itu sudah hilang.Ketika ajaran Islam berkembang, tradisi ritual ini tidak hilang, bahkan mengalami akulturasi dengan ajaran agama.Sehingga perilaku keagamaan tampak diwarnai dengan praktik agama lokal, bahkan oleh mereka dipahami bahwa praktik-praktik ritual tersebut dianggap sebagai keharusan dan bagian dari perilaku keagamaan.

Masyarakat di Kabupaten Bone adalah masyarakat yang mayoritas memeluk agama Islam, namun tidak dapat dipungkiri bahwa penduduk di daerah ini masih ada yang percaya dan terpengaruh dengan ajaran nenek moyang seperti animisme dan dinamisme. Warga masyarakat masih mempercayai adanya roh-roh serta kekuatan supranatural selain kekuatan dan kekuasaan Allah SWT. Pada umumnya masyarakat Bone juga masih percaya pada sejumlah hal yang dianggap tabu atau pantangan yang diterima dari nenek moyang masih dipegang oleh penduduk 
kalangan tua atau yang dalam bahasa bugis disebut pamali.

Sehubungan dengan hari baik dan hari buruk untuk melakukan sesuatu kegiatan seperti membangun rumah baru, melaksanakan pernikahan, bepergian jauh atau keluar merantau, dan memulai menanam benih.Masih cukup banyak masyarakat Bone yang mempercayai atau berpedoman dengan apa yang dikatakan oleh orang pintar tentang kapan hari baik atau buruk untuk melakukan sesuatu. Keberadaan Pesantren Modern AlJunaidiyah Biru sebagai Pendidikan Islam di kabupaten Bone tentunya memberikan sumbansi ilmu pengetahuan keagaamaan terhadap masyarakat. Sehingga secara tidak langsung dapat merubah pola pikir masyarakat untuk meninggalkan kepercayaan yang dianggap tidak sesuai dengan ajaran agama.

\section{E. Kesimpulan}

Dari uraian yang telah dibahas pada bab-bab sebelumnya, maka dapat ditarik kesimpulan sebagai berikut:

Sebelum didirikan Pesantren Modern Al-Junaidiyah Biru, KH. Junaid Sulaiman sebagai pendiri pesantren awalnya membuka pengajian kitab kuning yang berlokasi di masjid raya Watampone. Daya tampung masjid raya yang kecil dan minat masyarakat untuk belajar semakin meningkat kemudian menjadi alasan bagi KH. Junaid Sulaiman untuk membangun pusat pendidikan Islam yang lebih besar dan bisa lebih fokus membina generasi muda. Berkat komunikasi yang baik dengan bapak Bupati Kabupaten Bone Andi Muhammad Amir dan Dewan perwakilan Rakyat maka diperolehlah lokasi yang strategis di JL. Biru dan dengan bantuan berbagai pihak, berdirilah pesantren tersebut yang awalnya diramaikan oleh santri pindahan dari masjid raya, mereka kurang lebih 20 orang.

Pesantren Modern Al-Junaidiyah Biru disamping memiliki fasilitas bangunan yang dapat menunjang proses belajar mengajar juga memiliki sarana gedung yang sudah memadai. Ada asrama santri putra dan putri yang terdiri dari santri MA. MTs, PDF, dan Qismul Huffadz (penghafal AlQur'an). Ruang belajar santri, kantor sekolah, masjid yang digunakan sebagai tempat ibadah dan kegiatan santri, aula serbaguna, perpustakaan, gedung UKS, Koperasi santri, laboratorium komputer, laboratorium IPA, ruang multimedia, ruang osis, pramuka, dan olahraga, serta ruang makan santri. Semuanya dibangun dengan kontruksi kuat dengan desain gedung dan arsitektur yang indah dan menarik sehingga sangat mendukung kondisi dalam proses pembelajaran. Pesantren Modern AlJunaidiyah Biru mengalami perkembangan yang dapat terlihat dengan jelas seperti perkembangan sarana dan prasarana, tenaga pengajar, dan para santrinya yang setiap tahun jumlahnya terus bertambah.

Kurikulum yang diterapkan di Pesantren Modern Al-Junaidiyah Biru terdiri atas tiga yaitu; kurikulum pesantren, kurikulum Kementerian Agama, dan kurikulum umum. Kurikulum pesantren terdiri dari nahusharaf, mahfudzat, ushul fiqhi, ulumul hadits, ulumul Qur'an, kaligrafi, dan Qur'an hifdan.Kurikulum Kementerian Agama terdiri dari al-Qur'an hadits, akidah akhlak, fiqhi, bahasa Arab, dan sejarah kebudayaan Islam. Sedangkan kurikulum umum terdiri dari bahasa Indonesia, bahasa inggris, biologi, sejarah, pkn, sosiologi, matematika, dan lain sebagainya.

Model pembelajaran santri di Pesantren Modern Al-Junaidiyah Biru terdiri dari dua bentuk, yaitu; model full day, dan boarding school. Model full day diorientasikan pembelajaran pada santri yang tinggal atau mondok di pesantren. Maksudanya, santri lokal yang tidak tinggal di asrama aktivitas pembelajaran dimulai pada pagi hari sampai menjelang siang hari yang 
diperuntukkan untuk santri Raudhatul Athfal. sedangkan untuk santri TPA/TPQ jam belajar dimulai setelah dzuhur sampai sore hari. Selanjutnya untuk model pembelajaran boarding school santri harus mondok atau diasramakan dan wajib mengikuti regulasi, kode etik, dan proses pembelajaran yang ditetapkan oleh pondok pesantren.

Keberadaan Pesantren Modern AlJunaidiyah Biru di tengah-tengah masyarakat Kelurahan Biru membawa dampak tersendiri dalam hal keagamaan bagi masyarakat dan santri. Dampak yang dirasakan secara langsung oleh masyarakat tentunya mengetahui lebih dalam lagi tentang agama Islam. Dulunya masyarakat Kelurahan Biru Kecamatan Tanete Riattang sebelum didirikan pesantren sangat jarang terlihat masyarakat ke masjid untuk melaksanakan shalat berjamaah. Tetapi, setelah Pesantren Modern AlJunaidiyah Biru berdiri ditengah-tengah masyarakat Kelurahan Biru terlihat sangat jelas perbedaan sebelum dan sesudah berdirinya pesantren. Masyarakat Kelurahan Biru memiliki kesadaran dalam hal keagamaan dengan melaksanakan shalat berjamaah di masjid. Dalam hal ini jelas tampak bahwa keberadaan Pesantren Modern Al-junaidiyah Biru membawa dampak positif dalam hal keagamaan

\section{DAFTAR PUSTAKA}

A, D. (2015). Metode Penelitian Sejarah. Yogyakarta: Ombak.

Ahmad, I. (2019, Mei 4). Tenaga Pengajar Pertama di Pesantren Modern AlJunaidiyah Biru. (Nirwana, Interviewer)

Daulay, H. P. (2007). Sejarah Pertumbuhan dan Pembaruan Pendidikan Islam di Indonesia. Jakarta: Kencana.

Haryono. (1995). Mempelajari Sejarah Secara Efektif. Malang: Pustaka Jaya.
Hermanto. (2012). Analisis Tingkat Kemandirian Peserta Didik (Studi Pada Pesantren Modern AlJunaidiyah Biru Kabupaten Bone. Makassar: Tesis: UIN Alauddin.

Hidayat, M. (2016). Model Komunikasi Kyai dengan Santri di Pesantren . Komunikasi Aspikom, 6.

Indrawan , I. (2015). Pengantar Manajamen Sarana dan Prasarana Sekolah. Yogyakarta: Deepublish.

Ismail, B. (2014). Pesantren dan Bahasa Arab. Thariqah Ilmiah, 1.

M, D. H. (2008). Administrasi Pendidikan . Jakarta: Rineka Cipta.

Makmur, A. i. (2019, April 2). Fasilitas Alumni untuk melanjutkan studi ke perguruan tinggi. (Nirwana, Interviewer)

Minarti, S. (2013). Ilmu Pendidikan Islam. Jakarta: Bumi Aksara.

Muhaimin. (2014). Pengembangan Kurikulum Pendidikan Agama Islam. Jakarta: PT. Raja Grafindo Persada.

Nata, A. (2001). Metodologi Studi Islam. Jakarta: PT. Raja Grafindo Persada.

Reza, P. (2016). Manajemen Sarana dan Prasana Untuk Meningkatkan Mutu Pembelajaran. Universitas Negeri Makassar: Fakultas Ilmu Malang, 1.

Saigah, S. (2019, Mei 12). Dampak Pesantren dalam Bidang Pendidikan. (Nirwana, Interviewer)

Sardiman. (2005). Interaksi dan Motivasi Belajar Mengajar. Jakarta: PT. Raja Grafindo Persada.

Sjamsuddin, H. (2007). Metodologi Sejarah. Yogyakarta: Ombak.

Soyomukti, N. (2017). Teori-Teori Pendidikan. Yogyakarta: Ar-Ruz Media.

Umar. (2016). Eksistensi Pendidikan Islam di Indonesia. Uin Alauddin: Fakultas Tarbiyah Institut, 1.

Usman, I. (2013). Pesantren Sebagai Lembaga Pendidikan Islam. AlHikmah, 101. 